\title{
More Doctors Program: health work process and socioeconomic indicators
}

\author{
(D) Natércia Janine Dantas da Silveira ${ }^{1}$ \\ (D) Yan Nogueira Leite de Freitas ${ }^{2}$ \\ (iD Lyane Ramalho Cortez ${ }^{3}$ \\ (iD) Angelo Giuseppe Roncalli4
}

\begin{abstract}
1. Doutoranda do Programa de Pós-Graduação em Saúde Coletiva (PPGSCol) da Universidade Federal do Rio Grande do Norte (UFRN), Natal, RN, Brasil. 2. Professor Adjunto da Universidade Federal do Amazonas (UFAM), Manaus, AM, Brasil. 3. Professor Adjunta da Universidade Federal do Rio Grande do Norte (UFRN), Natal, RN, Brasil.
\end{abstract} 4. Professor Titular da Universidade Federal do Rio Grande do Norte (UFRN)., Natal, RN, Brasil.

http://dx.doi.org/10.1590/1806-9282.66.3.321

\section{SUMMARY}

OBJECTIVE: To analyze the working process of the professionals of the More Doctors Program and its relationship with socioeconomic indicators. It is a quantitative study, in which secondary data from supervision reports of PMM were used. The dependent variable was the quality of work processes in Primary Care facilities, and the independent ones were the type of municipality, education, Gini index, Primary Health Care investments, and health facilities coverage. Data were analyzed with multiple modeling based on Poisson regression with robust variance.

RESULTS: 16,000 doctors within 3816 municipalities were analyzed. Variables related to the working process the remained significant in the final model were the investments in Primary Health Care and the health facilities coverage. The results expressed the equity principle, as those municipalities with more vulnerable conditions and with higher coverage are prone to perform more activities in their working process.

CONCLUSIONS: The implementation of the More Doctors Program and hence the provision of doctors in deprived regions promoted the consolidation of three main aspects, namely the health working process, primary health care and equity, making it possible to carry out a health working process focused on PHC. This implies performing a greater number of activities that are inherent to PHC, which were not carried out due to the absence of doctors. The More Doctors Program fulfills its role in the combat of inequalities, particularly regarding more vulnerable municipalities.

KEYWORDS: Health Status Indicators. Primary Health Care. Health Services Coverage.

\section{INTRODUCTION}

Brasil is currently fighting for the survival of the Unified Health System (SUS). Among the many challenges, is the replacement of 8 thousand Cuban doctors who left the country in 2018 due to the end of the technical cooperation between Brasil and Cuba, putting at risk the access to assistance of 23 million people in 2,800 vulnerablemunicipalities ${ }^{1}$.
In the international context, several countries have adopted measures to tackle the shortcomings of human resources, in particular, of doctors, with emphasis on Canada, England, Holland, Portugal, Australia, the United States, and Chile ${ }^{1-5}$.

In 2013, Brasil presented a density of 1.85 doctors per thousand inhabitants. Five years later, in 2018,

DATE OF SUBMISSION: 15-Aug-2019

DATE OF ACCEPTANCE: $10-O c t-2019$

CORRESPONDING AUTHOR: Yan Freitas

Programa de Pós-Graduação em Saúde Coletiva do Rio Grande do Norte (PPGSCol) - Departamento de Odontologia da UFRN

Av. Sen. Salgado Filho, 1787 - Lagoa Nova, Natal, RN, Brasil - 59078-970

E-mail:nlfyan@hotmail.com 
that figure rose to 2.24 , below that of countries such as Canada (2.54 in 2015); the United Kingdom (2.83 in 2016), and Australia (3.5 in 2015). It should be emphasized that currently, in Brasil, only 823 municipalities have one or more doctors per thousand inhabitants and that there are 374 municipalities with one doctor for a thousand inhabitants ${ }^{6-9}$.

In this context, we had the Programa Mais Médicos (PMM - More Doctors Program), which was launched in July 2013, through Law No 12,871, to train human resources in the medical area of SUS in order to meet the rights provided for in the Constitution. This policy is structured around three strategic axes: training for the Single Health System (SUS); infrastructure improvement for Basic Health Units (UBS), and provision of emergency physicians ${ }^{10}$.

The PMM aims to reduce the shortage of doctors in priority regions, reduce inequalities in access to health care, strengthen Basic Health Care (ABS), improve medical training, expand the inclusion of training physicians in ABS, strengthen the policy of continuing education on service, promote the exchange of knowledge and experiences among Brazilian health professionals and doctors trained abroad, improve the training of doctors to work on SUS public policies and, finally, stimulate SUS-related research ${ }^{11}$.

In the face of the enormous demand for medical professionals, the program recruited Brazilian and foreign doctors. Initially, a small portion of the vacancies was occupied by Brazilian physicians trained in Brasil, followed by Brazilian physicians trained abroad, and, only then, by foreign doctors, with a preponderance of Cuban professionals, who occupied nearly $85 \%$ of the vacancies. In $2015,100 \%$ of the vacancies were occupied by Cuban doctors. In 2018, the cooperation between Brasil and Cuba was interrupted, which culminated with 8 thousand Cuban doctors leaving the project. There was enormous difficulty in finding Brazilian physicians to fill out this new vacancies'.

Added to this situation, the PMM is currently experiencing several challenges related to the perspective of its continuity. Thus, the ruptures in the work process caused by the replacement of the preexisting medical teams, the regional inequalities in the distribution of physicians, the instability for the permanent establishment of professionals, the deficiency in the management of work and education, the fragility of regional and hierarchical networks of health care, the absence of transformation in models of care/management, and the lack of quality assistance to the population represent the main challenges noted by the literature for the consolidation of the PMM ${ }^{6,11,12}$.

Faced with this reality, it seems clear there is a need to investigate the work process associated with the PMM, mainly regarding the provision of professionals in remote and vulnerable areas. Therefore, seeking associations between socioeconomic indicators and the work process of the program, in different realities, represents an important tool for planning and drafting policies capable of contributing to overcoming these challenges, particularly in order to justify the continuation of such a policy.

Thus, the present study aims to analyze the relationship between the work process of the physicians who participated in the Cuban cooperation with the PMM and some contextual socioeconomic indicators.

\section{METHODS}

It is a quantitative and observational study, in which we used secondary data from the first supervision visit report (2015) of the PMM, conducted in 3,816 Brazilian municipalities and involving 15,397 professionals.

The pedagogic supervision reports were filled out by the PPM supervisors and are available online, hosted on the website of the Ministry of Education. There are stored in a Webportfólio System/UNA-SUS.

The report is composed of personal data of the supervisor, the physician supervised, the work location of the supervised physician, health units, work process, health care, health care network, and continuing education. The database refers to physicians who participate in the Cuban cooperation, aiming to analyze the specific work process of the participating professionals.

In this study the work process was represented by a set of dependent variables, namely: (a) team meetings, (b) team acceptance, (c) physician participation in the acceptance, (d) discussion of the therapeutic project, (and) physician participation in home visits, (f) team planning, and (g) health indicators.

Were used, also, independent socioeconomic variables, selected from an exploratory study, in order to verify the viability of the model to be tested. Then we sought correlations between those and the main dependent variable (represented by the sum of all dependent variables cited previously). From these 
correlations, we excluded those that presented the greatest colinearity between themselves, in addition to being supported by the literature. In the end, we selected the following independent variables to compose the model: type of municipality, expectation of years of study, income inequality (Gini index), resources of basic care, and health units coverage.

Still in relation to the statistical analysis, we performed a descriptive analysis of the variables studied, followed by a grouping of the variables that constitute the work process, forming the main dependent variable with three categories: "performs all activities", "does not perform up to 2 activities", and "does not perform 3 or more activities". Subsequently, a bivariate analysis was performed by Pearson chisquare test $(p<0.05)$, to check the variables that were candidates to multiple regression. Then, we performed a Poisson regression with robust variance considering as the outcome the "number of activities not performed".

Finally, it is worth noting that this study involved secondary data; thus, it was not necessary to obtain any approval from the Research Ethics Committee.

\section{RESULTS}

We analyzed data from the reports of the first supervision visit of 3,816 municipalities, covering 15,397 professionals in Brasil. For the purposes of analysis, we excluded some municipalities that were not yet covered by the program.

The results revealed that some socioeconomic variables explain the work process model of the PMM, as shown in Tables 1 and 2.

Table 1 showed, from the bivariate analysis, that all variables had a significance level below 0.2 and, therefore, were included in the Poisson multiple regression model. The variable "expectation of years of study" was the only one not associated with the work process hours of the PMM physicians.

The results showed that the performance of a greater number of activities inherent to the work process of physicians in Primary Health Care occurred in the state capitals (41.8\%), in municipalities that had an average formal education of up to 9.16 years (37.5\%), with a higher Gini index (40.2\%), and lower Human Development Index (HDI) (40.2\%). It should be emphasized that the performance of all work process

TABLE 1. DESCRIPTIVE ANALYSIS OF THE VARIABLE RELATING TO THE WORK PROCESS IN RELATION TO THE SOCIOECONOMIC INDEPENDENT VARIABLES. BRASIL, 2019

\begin{tabular}{|c|c|c|c|c|c|c|c|}
\hline & \multicolumn{2}{|c|}{ Performs all activities } & \multicolumn{2}{|c|}{$\begin{array}{l}\text { Does not perform } 1 \text { to } 2 \\
\text { activities }\end{array}$} & \multicolumn{2}{|c|}{$\begin{array}{l}\text { Does not perform } 3 \text { or } \\
\text { more activities }\end{array}$} & \multirow[b]{2}{*}{$\mathrm{p}$} \\
\hline & $\mathrm{n}$ & $\%$ & $\mathrm{n}$ & $\%$ & $n$ & $\%$ & \\
\hline \multicolumn{8}{|l|}{ Type of Municipality } \\
\hline Capital & 839 & 41.8 & 729 & 36.3 & 438 & 21.8 & \multirow{2}{*}{$<0.001$} \\
\hline Interior & 5,289 & 35.7 & 5,192 & 35.0 & 4,338 & 29.3 & \\
\hline \multicolumn{8}{|c|}{ Expectation of years of study } \\
\hline Over 9.94 & 1,973 & 35.6 & 1,930 & 34.8 & 1,640 & 29.6 & \multirow{3}{*}{0.058} \\
\hline From 9.16 to 9.94 & 2,021 & 36.1 & 2,018 & 36.1 & 1,556 & 27.8 & \\
\hline Up to 9.16 & 2,134 & 37.5 & 1,973 & 34.7 & 1,580 & 27.8 & \\
\hline \multicolumn{8}{|l|}{ Gini Index } \\
\hline Up to 0.49 & 1,724 & 30.7 & 2,015 & 35.9 & 1,871 & 33.4 & \multirow{3}{*}{$<0.001$} \\
\hline From 0.491 to 0.550 & 2,189 & 38.4 & 1,936 & 33.9 & 1,578 & 27.7 & \\
\hline Over 0.550 & 2,215 & 40.2 & 1,970 & 35.7 & 1,327 & 24.1 & \\
\hline \multicolumn{8}{|l|}{ HDI } \\
\hline Over 0.737 & 1,938 & 35.3 & 1,947 & 35.4 & 1,610 & 29.3 & \multirow{3}{*}{$<0.001$} \\
\hline From 0.643 to 0.37 & 1,929 & 35.4 & 2,066 & 36.2 & 1,713 & 30.0 & \\
\hline Up to 0.643 & 2,261 & 40.2 & 1,908 & 33.9 & 1,453 & 25.8 & \\
\hline \multicolumn{8}{|c|}{ Per capita investment in APS } \\
\hline Over 43.3 & 2,196 & 39.2 & 1,994 & 35.6 & 1,412 & 25.2 & \multirow{3}{*}{$<0.001$} \\
\hline From 28.3 to 43.3 & 2,027 & 35.6 & 2,048 & 36.6 & 1,523 & 27.2 & \\
\hline Up to 28.3 & 1,905 & 33.9 & 1,879 & 33.4 & 1,841 & 32.7 & \\
\hline \multicolumn{8}{|l|}{ Health Units Coverage } \\
\hline Over 1.76 & 2,068 & 37.0 & 2,056 & 36.8 & 1,460 & 26.1 & \multirow{3}{*}{$<0.001$} \\
\hline From 0.69 to 1.76 & 1,989 & 35.6 & 2,006 & 35.9 & 1,589 & 28.5 & \\
\hline Up to 0.69 & 2,038 & 36.5 & 1,841 & 33.0 & 1,708 & 30.6 & \\
\hline
\end{tabular}


activities occurred in municipalities with higher per capita investment in APS (39.2\%), associated to greater coverage of Basic Health Units (367\%).

In relation to municipalities that did not perform three or more activities related to the work process, the data showed that these were concentrated in the interior (29.3\%), in municipalities that had a higher expectation of years of study (29.3\%). It also occurred in cities with the lower Gini indexes (40.2\%), more developed (HDI, 25.8\%), lower per capita investment in APS (25.2\%), and with lower coverage of Health Units (26.1\%).

Table 2 presents the results of the multiple regression, in which the HDI variable lost significance. With the multiple regression, the municipalities with an expectation of up to 9.16 years of study began to show a direct relationship with the prevalence of activities not performed. The same occurred for municipalities with per capita investment in APS of up to R\$28.30.

\section{DISCUSSION}

The research evidences the three pillars in health: equity, work process, and primary health care, and showed that the most vulnerable municipalities performed a greater number of activities inherent to the work process of APS. However, the activities analyzed in this study (which make up the work process) are not on the sphere of innovation or invention but are inherent to the routine of Primary Health Care and the production of health care.

Santos et al. ${ }^{9}$ highlight the activities provided for in the National Policy of Basic Care (Pnab), for example, regular meetings for the planning of health actions, home visits, and educational activities that became routine only after the deployment of the PMM.

In relation to the type of municipality, the study found there was the consolidation of a greater number of activities in capitals due to the existence of more appropriate infrastructure and greater ease of access in comparison with the interior. This is a counterpoint to the study conducted by Carneiro et al. ${ }^{13}$ and Santos et al. ${ }^{9}$, who aimed to evaluate the performance of the Family Health Strategy (ESF) after the implementation of the PMM in the territory of Marajó-PA, noting that the PMM fulfilled its role with greater effectiveness in coastal regions, areas of difficult access on the island of Marajó ${ }^{13}$.

The data found in this study show there is a link between the three variables - coverage, per capita health investment, and the Gini index - which are considered strategic in the analysis of public policy, indicating that the allocation of resources, in the perspective of the PMM, occurs in municipalities that

TABLE 2. POISSON REGRESSION MODELING TO CHECK THE RELATIONSHIP BETWEEN THE INDEPENDENT AND DEPENDENT VARIABLES ( $N=16,825)$. BRASIL, 2019

\begin{tabular}{|c|c|c|c|c|c|}
\hline \multirow[b]{2}{*}{ Variables } & \multirow{2}{*}{$\begin{array}{l}\text { Activities not performed } \\
\text { Mean }(95 \% \mathrm{Cl}) \\
\end{array}$} & \multicolumn{4}{|c|}{ Prevalence Ratios (PR) by Poisson Regression } \\
\hline & & Unadjusted & & Adjusted & \\
\hline Type of Municipality & & $\mathrm{PR}(95 \% \mathrm{Cl})$ & $\mathrm{P}$ & $\mathrm{PR}(95 \% \mathrm{Cl})$ & $p$ \\
\hline Capital & $1.44(1.36-1.51)$ & 1 & & 1 & \\
\hline Interior & $1.80(1.77-1.83)$ & $1.25(1.20-1.30)$ & $<0.001$ & $1.30(1.24-1.36)$ & $<0.001$ \\
\hline \multicolumn{6}{|l|}{ Expectation of years of study } \\
\hline Over 9.94 & $1.82(1.77-1.87)$ & 1 & & 1 & \\
\hline From 8.16 to 9.94 & $1.75(1.69-1.80)$ & $0.96(0.93-0.99)$ & 0.005 & $1.03(1.00-1.06)$ & 0.028 \\
\hline Up to 9.16 & $1.71(1.66-1.76)$ & $0.94(0.91-0.96)$ & $<0.001$ & $1.04(1.01-1.08)$ & 0.007 \\
\hline \multicolumn{6}{|l|}{ Gini Index } \\
\hline Up to 0.49 & $2.02(1.97-2.08)$ & 1 & & 1 & \\
\hline From 0.491 to 0.550 & $1.70(1.64-1.74)$ & $0.83(0.81-0.85)$ & $<0.001$ & $0.86(0.84-0.89)$ & $<0.001$ \\
\hline Over 0.550 & $1.56(1.51-1.61)$ & $0.77(0.75-0.79)$ & $<0.001$ & $0.84(0.81-0.87)$ & $<0.001$ \\
\hline \multicolumn{6}{|c|}{ Per capita investment in APS in reais } \\
\hline Over R\$ 43.3 & $1.58(1.53-1.63)$ & 1 & & 1 & \\
\hline From $R \$ 28.3$ to $R \$ 43.3$ & $1.71(1.66-1.76)$ & $1.08(1.04-1.1)$ & $<0.001$ & $1.10(1.07-1.13)$ & $<0.001$ \\
\hline Up to $\mathrm{R} \$ 28.3$ & $1.98(1.92-2.03)$ & $0.89(0.86-0.91)$ & $<0.001$ & $1.28(1.23-1.32)$ & $<0.001$ \\
\hline \multicolumn{6}{|c|}{ Coverage of Health Units (UBS/10,000 inhabitants) } \\
\hline Over 1.76 & $1.65(1.60-1.70)$ & 1 & & 1 & \\
\hline From 0.69 to 1.76 & $1.80(1.72-1.82)$ & $1.07(1.04-1.10)$ & $<0.001$ & $1.04(1.00-1.07)$ & 0.011 \\
\hline Up to 0.69 & $1.85(1.80-1.91)$ & $1.12(1.09-1.15)$ & $<0.001$ & $1.07(1.04-1.12)$ & $<0.001$ \\
\hline
\end{tabular}


are more vulnerable, have more UBS coverage, and greater health inequality ${ }^{11}$.

Coverage is a relevant indicator in the assessment of APS and the performance of Family Health Teams in Brasil since it provided better access to health services and systems. The results demonstrate that municipalities with a smaller population have greater coverage by the ESF, which does not necessarily translate into greater geographical or organizational accessibility ${ }^{10.11}$.

Kemper et al. ${ }^{14}$ highlight that with the implementation of the PMM there was an expansion of coverage. Currently, Brasil has more than 40,000 Family Health Teams deployed, responsible for the coverage of 130 million people. The PMM has contributed to the reduction of the shortage of physicians in priority and vulnerable areas, such as the North and Northeast regions, reaffirming the principle of fairness that was stressed in this research ${ }^{12}$.

In relation to investments in primary health care, it was found that the more resources allocated to vulnerable areas, the further the development of APS. Research conducted by Mendonça et al. ${ }^{15}$ aimed at evaluating primary health care based on the methodology by Starfield and Shy concluded that municipalities with very low per capita expenditures are associated with worse APS scores, which is in line with those of European countries, which related the improvement of primary care with better populational health status, lower rates of hospitalization, and lower socioeconomic inequality, and the overall expenditure in health is better in countries with better APS.

However, in the context of SUS, APS has been marked by a trajectory of reduction of resources due to the underfinancing of the system structure ${ }^{16}$. By the end of 2017, Brasil experienced a downsizing of Basic Care, not only regarding resources but in its conception and financing. We face a scenario of health "de-financing", which may culminate in the annihilation of the attempts of building a universal system and, particularly, of Primary Health Care. Indeed, there were drastic cuts in public spending, justified by an attempt to achieve fiscal balance. The Constitutional Amendment (EC) 95/2016 limited public spending (primary expenditure) for 20 years. There was a loss of $\mathrm{R} \$$ 9.2 billion in the budget of the Ministry of Health in 2016, which intensified the underfinancing of SUS ${ }^{16}$.

FIGURE 1. DESCRIPTION OF THE DEPENDENT AND INDEPENDENT VARIABLES. BRASIL, 2019

\begin{tabular}{|c|c|c|}
\hline \multicolumn{3}{|c|}{ Dependent Variables } \\
\hline Variable & Description & Categories \\
\hline Acceptance & Refers to the way one welcomes others or is welcomed. & $\begin{array}{l}\text { Yes } \\
\text { No }\end{array}$ \\
\hline Physician acceptance & Refers to the presence of the physician in the act or way of welcoming others. & $\begin{array}{l}\text { Yes } \\
\text { No }\end{array}$ \\
\hline $\begin{array}{l}\text { Discussion of the therapeutic } \\
\text { project by the team }\end{array}$ & $\begin{array}{l}\text { It is a set of proposals and therapeutic conducts articulated to a individual and group as the } \\
\text { result of a collective discussion by an interdisciplinary team. }\end{array}$ & $\begin{array}{l}\text { Yes } \\
\text { No }\end{array}$ \\
\hline Home visit by a physician & $\begin{array}{l}\text { It is a type of care targeted at a family or an individual provided in households or in partner- } \\
\text { ship with local social resources, also with the presence of a physician. }\end{array}$ & $\begin{array}{l}\text { Yes } \\
\text { No }\end{array}$ \\
\hline Team planning & Developing a team plan to reach a certain goal. & $\begin{array}{l}\text { Yes } \\
\text { No }\end{array}$ \\
\hline Health indicators & $\begin{array}{l}\text { Parameters used internationally to assess, from a health point of view, the healthiness of } \\
\text { human groupings, as well as provide subsidies for health plans. }\end{array}$ & $\begin{array}{l}\text { Yes } \\
\text { No }\end{array}$ \\
\hline \multicolumn{3}{|c|}{ Independent Variables } \\
\hline Variable & Description & Categories \\
\hline Type of Municipality & $\begin{array}{l}\text { Classification of the municipality in relation to its representation in the state of which it is } \\
\text { part. }\end{array}$ & $\begin{array}{l}\text { Capital } \\
\text { Interior }\end{array}$ \\
\hline $\begin{array}{l}\text { Expectation of years of study } \\
\text { at age } 18\end{array}$ & $\begin{array}{l}\text { Average number of years of study that a generation of children who enters school must } \\
\text { complete by the age of } 18 \text { years, if current standards are maintained throughout the school } \\
\text { life. }\end{array}$ & $\begin{array}{l}\text { Years of formal } \\
\text { education }\end{array}$ \\
\hline Gini Index & $\begin{array}{l}\text { Measures the degree of inequality in the distribution of individuals according to the per } \\
\text { capita household income. It varies from } 0 \text {, when there is no inequality (the per capita } \\
\text { household income of all individuals is the same), to 1, indicating maximum inequality (a } \\
\text { single individual is responsible for all the income). The universe of individuals is limited to } \\
\text { those living in permanent private households. }\end{array}$ & O a 1 \\
\hline HDI & $\begin{array}{l}\text { Geometric average of the indices of income, education, and longevity dimensions, with } \\
\text { equal weights. }\end{array}$ & O a 1 \\
\hline Basic Care Resources & Amount invested in primary care, divided by the total population in 2010. & Reais per capita \\
\hline Health Units Coverage & $\begin{array}{l}\text { Number of primary care teams (Family Health Program) multiplied by } 3,450 \text {, divided by the } \\
\text { total population. }\end{array}$ & $1: 10,000$ \\
\hline
\end{tabular}


The authors add that the impacts are immediate and direct on work processes of health teams and the health conditions of the population, reflecting, crosswise, in the work process of the teams and the main health indicators, such as, increased infant mortality, decreased supply of vaccine coverage, thus, hindering hospital care and the development of actions and services of basic care ${ }^{16}$.

\section{CONCLUSIONS}

It can be concluded that the provision of physicians in unassisted regions allowed for a work process with strong evidence of the principle of equity. With the implementation of the PMM, teams went on to perform a greater number of activities, improving the work process and bringing it closer to the attributes of APS.

Socioeconomic variables are fundamental to explain the work process with the deployment of the
PMM in Brazilian municipalities. In our study, the pillar of financing and coverage of basic care stand out for accomplishing a work process that is consistent with the actual needs of the population, considering that the allocation of resources to the most vulnerable regions can enable an improvement in the infrastructure of units, a greater number of human resources, inputs, and equipment, which are essential for a better quality of care.

As discussed, in order to strengthen Primary Health Care and to achieve an effective work process, it is essential to invest in and increase coverage in unassisted and vulnerable areas. However, it is also necessary that medical professionals display sensitivity and flexibility in a health team in order to effectively carry out the activities that are already part of the work process in Primary Health Care.

\section{Authors Contribution}

All authors contributed equally to this study.

\section{RESUMO}

OBJETIVO: Analisar a relação entre o processo de trabalho dos médicos do Programa Mais Médicos (PMM) no Brasil e alguns indicadores socioeconômicos no período de 2015.

MÉTODO: Trata-se de uma pesquisa quantitativa que utilizou dados secundários dos relatórios de supervisão do PMM. A variável dependente foi a qualidade do processo de trabalho e as variáveis independentes foram o tipo de município, expectativa de anos de estudo, índice de Gini, investimento em Atenção Primária à Saúde (APS) e cobertura de unidades de saúde. Na análise dos dados foi realizada a modelagem múltipla por regressão de Poisson com variância robusta.

RESULTADOS: Foram analisados dados de 3.816 municípios, abrangendo 1.537 profissionais. Destacam-se como variáveis socioeconômicas estratégicas e que explicam o modelo do processo de trabalho do PMM: o investimento e a cobertura da atenção básica. Tornou-se bastante evidente o princípio da equidade, pois os municípios mais vulneráveis e de maior cobertura realizam maior número de atividades em seu processo de trabalho.

CONCLUSÕES: Com a implantação do PMM e o provimento de médicos em regiões desassistidas ocorreu a consolidação do tripé processo de trabalho em saúde, atenção básica e equidade, tornando possível a efetivação de um processo de trabalho focado na APS. Isso implica a realização de maior número de atividades inerentes à APS, as quais não eram realizadas em função da ausência do profissional médico. Nesse sentido, o programa cumpre o seu papel de combater as desigualdades em municípios mais vulneráveis.

PALAVRAS-CHAVE: Indicadores básicos de saúde. Atenção Primária à Saúde. Cobertura de serviços de saúde.

\section{REFERENCES}

1. Lima LD, Carvalho MS, Coeli CM. Médicos, política e sistemas de saúde Cad Saúde Pública. 2019;35(1):e00237418.

2. Brandão JRM. A atenção primária à saúde no Canadá: realidade e desafios atuais. Cad Saúde Pública. 2019;35(1):e00178217.

3. Carvalho VKS, Marques CP, Silva EN. A contribuição do Programa Mais Médicos: análise a partir das recomendações da OMS para provimento de Médicos. Ciênc Saúde Coletiva. 2016;21(9):2773-84.

4. GBD 2016 Healthcare Access and Quality Collaborators. Measuring performance on the Healthcare Access and Quality Index for 195 countries and territories and selected subnational locations: a systematic analysis from the Global Burden of Disease Study 2016. Lancet. 2018;391(10136):2236-71.
5. Rourke J. Increasing the number of rural physicians. (MA). 2008;178(3):322-5.

6. Scheffer M. Para muito além do Programa Mais Médicos. Ciênc Saúde Coletiva. 2016;21(9):2664-6.

7. Giovanella L, Mendonça MHM, Fausto MCR, Almeida PF, Bousquat A, Lima $\mathrm{G}$, et al. A provisão emergencial de médicos pelo Programa Mais Médicos e qualidade da estrutura das unidades básicas de saúde. Ciênc Saúde Coletiva. 2016;21(9):2697-708.

8. Scheffer M. Demografia médica no Brasil: cenários e indicadores de distribuição [relatório de pesquisa]. São Paulo: CRM-SP; CFM;2013. 
9. Santos W, Comes Y, Pereira LL, Costa AM, Merchan-Hamann E, Santos LMP. Avaliação do Programa Mais Médicos: relato de experiência. Saúde Debate. 2019;43(120):256-68.

10. Girardi SN, van Stralen ACS, Cella JN, Wan Der Maas L, Carvalho CL, Faria EO. Impacto do Programa Mais Médicos na redução da escassez de médicos em Atenção Primária à Saúde. Ciênc Saúde Coletiva. 2016;21(9):2675-84.

11. Facchini LA, Batista SR, Silva Jr AG, Giovanella L. O Programa Mais Médicos: análises e perspectivas. Ciênc Saúde Coletiva. 2016;21(9):2652.

12. Weber CAT. Dialectics of a medical provision policy in priority areas in Brasil. Rev Assoc Med Bras (1992). 2017;63(3):268-77.

13. Carneiro VB. Maia CRM, Ramos EMLS, Castelo-Branco S. Tecobé no Marajó: tendência de indicadores de monitoramento da atenção primária antes e durante o Programa Mais Médicos para o Brasil. Ciênc Saúde Coletiva. 2018;23(7):2413-22

14. Kemper ES, Mendonça AVM, Sousa MF. Programa Mais Médicos: panorama da produção científica. Ciênc Saúde Coletiva. 2016;21(9):2785-96.

15. Mendonça CS, Diercks MS, Kopittke L. O fortalecimento da Atenção Primária à Saúde nos municípios da Região Metropolitana de Porto Alegre, Brasil, após a inserção no Programa Mais Médicos: uma comparação intermunicipal. Ciênc Saúde Coletiva. 2016;21(9):2871-8.

16. Mendes A, Carnut L, Guerra LDS. Reflexões acerca do financiamento federal da Atenção Básica no Sistema Único de Saúde. Saúde Debate. 2018;42(n. spe1):224-43. 